\title{
Tuberculose Urinária: um importante diagnóstico diferencial. Relato de caso
}

\author{
Mendonça, J.L.; Hannusch, D.C.; Woytovetch, C.A.; Rossi, F.S.; Lopes, L.M.; \\ Zanatta, P.;
}

Apresentador: Juliana Leme Mendonça

\section{Resumo}

Introdução: A Tuberculose (TB) é importante causa de morbimortalidade em todo o mundo, sendo o trato genitourinário o segundo local extrapulmonar mais acometido. No envolvimento renal ocorre formação de granulomas corticais que levam a nefrite intersticial e calcificação. Os sintomas são insidiosos e incluem mal estar, disúria e hematúria. Em fases mais avançadas pode haver uropatia obstrutiva, infertilidade, perda da função renal, hipertensão refratária. O diagnóstico da tuberculose genitourinária (TBGU) é feito na presença dos sintomas e achados da urinálise (hematúria, leucocitúria sem bacteriúria, proteinúria) além de evidências de infecção atual ou pregressa pelo Mycobacterium tuberculsis (MTB) ou Bacilo de Koch (BK). A confirmação é feita pela demonstração do BK na urina por cultura (padrão-ouro), pesquisa direta de BK ou pesquisa de MTB por PCR. O tratamento da TBGU é o mesmo da TB pulmonar, com Rifampicina, Isoniazida, Pirazinamida e Etambutol por 2 meses, seguidos por 4 meses de Rifampicina e Isoniazida. Relato de Caso: G.L.D.R., masculino, 49 anos, interna com oligúria, disúria, dor em baixo ventre e febre. Múltiplos tratamentos para infecção do trato urinário nos últimos 2 anos sem resolução dos sintomas. $\mathrm{Na}$ admissão apresentava discreta anemia hipocrômica, leucograma, função renal e eletrólitos normais. Rx de tórax normal e sem queixas respiratórias. EAS com proteinúria + , nitrito negativo, leucocitúria e hematúria microscópicas, bacterioscopia negativa e $\mathrm{pH}$ 7,0. $\mathrm{PCR}=22,50 \mathrm{mg} / \mathrm{L}$. US com moderada dilatação pielocalicial. Foi iniciado ciprofloxacino endovenoso. Durante o internamento paciente manteve-se febril, com sintomas urinários e piúria mantida. Urocultura negativa, PSA normal. Tomografia com sinais de pielonefrite esquerda, hidronefrose esquerda, calcificações em bexiga e ureteres terminais. No $6^{\circ}$ dia de internação Rx tórax demonstrou alterações compatíveis com TB miliar, confirmado em tomografia de tórax. Anti-HIV negativo. 3 amostras de BK e fungos no escarro negativas. A pesquisa direta de BK na urina foi positiva. Iniciada terapia com Rifampicina, Isoniazida, Pirazinamida e Etambutol, com melhora sintomática e laboratorial. Recebeu alta hospitalar e segue acompanhamento ambulatorial. Conclusão: A hipótese de TBGU é um importante diagnóstico diferencial a ser lembrado na presença de sintomas urinários e piúria estéril pois o diagnóstico precoce permite instituir terapia específica com melhora dos sintomas e minimização das sequelas.

\section{Referência:}

Mendonça, J.L.; Hannusch, D.C.; Woytovetch, C.A.; Rossi, F.S.; Lopes, L.M.; Zanatta, P.;. Tuberculose Urinária: um importante diagnóstico diferencial. Relato de caso. In: II Congresso Brasileiro de Medicina Hospitalar - II CBMH [= Blucher Medical

Proceedings, vol.1, num.5] São Paulo: Editora Blucher, 2014. p.93

DOI 10.5151/medpro-II-cbmh-092 